\title{
Stress Induced Callus Initiation and Shoot Regeneration in Ovary Culture of Marigold (Tagetes spp)
}

\author{
Thaneshwari $^{*}$, C. Aswath ${ }^{2}$ and N. Chaithra ${ }^{3}$ \\ ${ }^{1}$ ICAR- Indian Agricultural Research Institute, New Delhi- 110 012, India \\ ${ }^{2}$ Division of Floriculture and Medicinal Crops-ICAR-Indian Institute of Horticultural \\ Research, Bengaluru, 560 089, Karnataka, India \\ ${ }^{3}$ SRF, MSc (Agri) Plant Biotechnology, Division of Floriculture and Medicinal Crops-ICAR- \\ Indian Institute of Horticultural Research, Bengaluru, 560 089, Karnataka, India \\ *Corresponding author
}

A B S T R A C T

Marigold is an important ornamental plant grown as garden plant and for flower decoration. It has been recognized as a key source of carotenoids; exclusively used in Pharmaceutical industries and poultry feed additives. However, improvement of this

Keywords

Ovary culture,

Gynogenesis, Plant

regeneration, Stress

treatments, Tagetes

erecta, Haploids

Article Info

Accepted:

26 February 2018

Available Online:

10 March 2018 valuable species is hampered by its high heterozygosity, but presently the greatest emphasis is on development of haploids through ovary culture, the efficient and timesaving technique in varietal improvement. As different factors affect the outcome in the ovary culture to produce haploids, thus present research was conducted to investigate effect of different stress (heat shockto flower buds, varying concentrations of sucrose in media and different durations of light-dark periods) on proliferation of ovary-derived callus, and its subsequent regeneration in marigold cultivar Arka Agni. Accordingly, pretreatment of flower buds at $45{ }^{\circ} \mathrm{C}$ for $2 \mathrm{hr}$ resulted in best callus induction and shoot differentiation, while Murashige and Skoog (MS) media supplemented with $4 \%$ sucrose, 4.44 $\mu \mathrm{M}$ BAP and 4.52 $\mu \mathrm{M} 2,4-\mathrm{D}$, incubated in dark for 4 weeks at $25^{\circ} \mathrm{C}$ yielded highest callus induction $(89.66 \%)$. Further, sub culturing on MS media supplemented with $4 \%$ sucrose, $4.44 \mu \mathrm{M}$ BAP and $1.07 \mu \mathrm{M}$ NAA exposed to $16 / 8 \mathrm{hr}$ photoperiod lead to highest shoot differentiation rate $(23.35 \%)$. Subsequently, regenerated shoots rooted readily on hormone free MS media.

\section{Introduction}

Marigold (Tagetes spp.), is native to Maxico and belongs to the Asteraceae family. It is an economically important flower crop. The genus is rich in lutein that is currently being used as food colourants (INS-number E161b) in the European Union. Extract of marigold flower can be used for coloration of $100 \%$ cotton, silk and wool fabrics. Because of this wide range of applications, marigold could represent an interesting alternative crop for more extensive cultivation. However, improvement of this valuable species has been hampered by its high heterozygosity. In addition, producing homozygous lines by conventional methods is time-consuming and takes long time and moreover difficult as these 
species prefer cross pollination. Thus, available haploid lines in marigold can be used for obtaining homozygous doubled haploid true breeding lines via androgenesis or gynogenesis, further providing marigold breeders a means to accelerate cultivar development.

In marigold, anther culture was employed for the production of androgenic haploids, but only callus mediated embryogenesis was obtained [Li et al., (2007), Yingchun et al., (2011)].However, ovules can be a possible alternative source for haploid production in plants, particularly in species where microspores or pollens are not much responsive to manipulation in vitro (Wędzony et al., 2009). Gynogenesis is, therefore, one of the methods used for obtaining haploid plants through culturing of un-pollinated ovules in vitro and successful production of gynogenic haploids has been reported in several crop species including wheat, maize, rice, onion, sugar beet, cucumber, carnation, squash, gerbera, sunflower, wheat, barley etc (Chen et al., 2011).

Different factors affect the outcome of the ovary culture techniques to produce haploid plants. Nevertheless, one of the important factors is the type of stress applied like temperature as pretreatment to the flower buds, excess or deficiency of carbohydrate in culture media and exposure of cultured ovary to different dark-light durations(Bohanec, 2009). Furthermore, the female gametophyte is usually immature at inoculation and, in contrast to androgenesis, its development continues during in vitro culture, leading to a mature embryo sac [Musial et al., (2005)]. As mature embryo sacs contain several haploid cells theoretically capable of forming haploid embryos, such as the egg cell, synergids, antipodal cells and non-fused polar nuclei, however, under optimal conditions, the egg cells in most gynogenetic responsive stage undergo sporophytic development (haploid parthenogenesis) (Bohanec, 2009). and can develop into haploid plants directly, avoiding the risk of gametoclonal variation, or through an intermediate callus phase. Thus, this study aims to determine the effect of series of stress like heat shock as pretreatment to flower bud, varying concentrations of sucrose in induction media and different dark-light durations on callus induction, necessary to initiate callusing and shoot differentiation in marigold through ovary culture.

\section{Materials and Methods}

\section{Plant material}

Marigold cultivar 'Arka Agni' plants were grown following standard package and practice.

\section{Methods}

Effect of heat shock as pretreatment on callus induction and shoot differentiation rate

Healthy and young flower buds of length 20 $\mathrm{mm}$ were collected from the shade net house during morning hours between 9:00 am to 09:30 am. Flower buds were wrapped in tissue paper and then in aluminium foil and finally sealed in the polythene bags separately. They were then exposed to temperature $\left(25{ }^{\circ} \mathrm{C}\right.$ in growth chamber and $35^{\circ} \mathrm{C}, 45^{\circ} \mathrm{C}$ in oven) for $1,2,5$ and $8 \mathrm{hr}$.

These heat pretreated buds were initially placed under running tap water for 15 minutes. Later, under aseptic conditions, these buds were surface sterilised with $0.1 \%$ carbendazim for 15 minutes, followed by rinsing with sterile distilled water. Subsequently, these buds were then disinfected by dipping in $70 \%$ ethanol for 30 seconds and in $1 \% \mathrm{NaOCl}$ for 5 minutes followed by 3 washes with sterile 
water and blotted dry with aseptic filter papers. Finally, sterilized buds were then cut vertically in two half with the sterile blade and kept on sterile filter paper for drying. Further, ovaries were precisely cut off from the florets, then all the ovaries from individual floret were taken out with the help of sterile blade and needle and inoculated immediately on to MS media (Murashige and Skoog, 1962) supplemented with $4.44 \mu \mathrm{M}$ BAP and 4.52 $\mu \mathrm{M} 2,4$ - D for callus induction. Seventy ovaries were placed on each plate. Subsequently, these calli were transferred to MS regeneration medium supplemented with $4.44 \mu \mathrm{M}$ BAP and $1.07 \mu \mathrm{M}$ NAA and maintained at $25 \pm 1{ }^{\circ} \mathrm{C}$ under $16 \mathrm{~h} / 8 \mathrm{hr}$ light/dark period. Thus, twelve treatment combinations $\left(25^{\circ} \mathrm{C}, 35^{\circ} \mathrm{C}\right.$ and $45^{\circ} \mathrm{C}$ for 1,2 , $5,8 \mathrm{hr}$ ) were tested using factorial complete random design, with 5 replicates for each type of treatment. However, ovary cultures were incubated at $25 \pm 1{ }^{\circ} \mathrm{C}$ in darkness until callus formed.

\section{Effect of sucrose concentration on callus induction and shoot differentiation rate}

Flower buds were collected as described in 2.2.1 and were exposed to $45^{\circ} \mathrm{C}$ for $2 \mathrm{hr}$. These pretreated flower buds were surface sterilized by the same method given in 2.2.1 and then ovary from these flower buds were inoculated on MS media supplemented with varying concentration of sucrose $(0 \%, 2 \%$, $4 \%, 6 \%, 8 \%, 10 \%$ and $12 \%$ ) and $4.44 \mu \mathrm{M}$ BAP and $4.52 \mu \mathrm{M} 2,4 \mathrm{D}$. These cultured ovary and induced calluses from them were maintained and sub-cultured same way as given in 2.2.1.

\section{Effect of dark treatment on callus induction and shoot differentiation rate}

Flower buds were collected as described in 2.2.1 and were exposed to $45^{\circ} \mathrm{C}$ for 2 days. These pretreated flower buds were surface sterilized by the same way given as in 2.2.1.
Ovaries were inoculated on MS media having $4 \%$ sucrose $+4.44 \mu \mathrm{M}$ BAP and $4.52 \mu \mathrm{M} 2,4$ D. These cultured plates were subjected to 0 , 1, 2, 3, 4, 5 and 6 weeks dark treatment. After dark period treatment, each plate was transferred to a $16 \mathrm{hr}$ photoperiod. Size and percentage of callus induction were recorded after 6 weeks of ovary culture.

\section{Plantlet rooting and transplanting}

Healthy shoots differentiated from green calli with 3 - 4 true leaves were excised from the culture and transferred to one of four types of rooting media. All rooting media consisted of MS salts, 3\% sucrose, $0.8 \%$ agar, and $\mathrm{pH}$ adjusted to 5.75-5.80. Each type was supplemented with four levels of IBA $(0,0.49$, 0.98 and $1.47 \mu \mathrm{M}$ ) and subjected to autoclaving as previously described. The welldeveloped plantlets were acclimatized for ten days. Subsequently, the plantlets were washed with tap water to remove traces of the medium and transferred to pots containing coco peat (Fig. 3).

\section{Data collection and analysis}

The ovary cultured plates were examined and data was recorded on percentage of callus induction, days to callus initiation and size of callus. Days to callus initiation was recorded when $50 \%$ of the ovaries callused per plate. The size of the callus was recorded 25 days after ovary culture in all the experiment except in dark treatment (2.2.3).

The callus induction and regeneration frequencies were calculated as callus induction rate $(\%)=$ number of ovaries producing calli/number of ovaries plated $\mathrm{x}$ 100 ; shoot differential rate $(\%)=$ number of calli differentiated into shoot/ number of calli transferred $\mathrm{x}$ 100. Analysis of variance (ANOVA) was conducted using Web Based Agricultural Statistics Software (WASP). 


\section{Results and Discussion}

Effect of heat pretreatment temperature on callus induction and shoot differentiation rate

Accordingly, $25{ }^{\circ} \mathrm{C}$ pretreatment was found to be significantly superior from all the other treatments in the terms of callus induction rate $(87.90 \%)$ and minimum days to callus induction (21.00 days), while Pretreatment of flower buds at $35{ }^{\circ} \mathrm{C}$ resulted in largest callus size $(7.70 \mathrm{~mm})$ which was found to be statistically superior from all other treatments. However, maximum shoot differentiation rate $(10.78 \%)$ was reported from the ovary of flower buds pretreated at $45^{\circ} \mathrm{C}$ (Table 1).

As the duration of exposure of buds to heat as pretreatment increases from $2 \mathrm{hr}$ to $5 \mathrm{hr}$ the callus induction rate and calli size decreases significantly. Accordingly, maximum callus induction rate $(89.66 \%)$, minimum days to callus induction (21.00 days) was reported when flower buds were pretreated for $1 \mathrm{hr}$, whereas maximum calli size with maximum callus induction rate $(89.66 \%)$ was found when flower buds were pretreated for $2 \mathrm{hr}$. On the other hand, maximum shoot differentiation rate $(12.66 \%)$ was observed when flower buds were pretreated for $5 \mathrm{hr}$ which was found to be significantly at par with $2 \mathrm{hr}$ pretreatment (12.38\%) (Table 2).

Thus, maximum callus induction $(89.66 \%)$ was reported when ovaries were pretreated at $25^{\circ} \mathrm{C}, 35^{\circ} \mathrm{C}$ for 1,2 or $5 \mathrm{hr}$ and at $45^{\circ} \mathrm{C}$ for 1 or $2 \mathrm{hr}$ which were found to be statistically superior from other treatment combination. Nonetheless, $45{ }^{\circ} \mathrm{C}$ for $8 \mathrm{hr}$ pretreatment drastically reduced the callus induction rate (46.67) and also resulted in smallest size calli $(1 \mathrm{~mm})$. In addition, minimum days to callus initiation (20.60 days) was found to be when ovaries/ flower buds were pretreated at $35^{\circ} \mathrm{C}$ for $2 \mathrm{hr}$, showing statistically at par with the treatments when ovaries were heat pretreated at; $25{ }^{\circ} \mathrm{C}$ for $1,2,5$ and $8 \mathrm{hr}$; at $35^{\circ} \mathrm{C}$ for 1 and $5 \mathrm{hr}$; at $45{ }^{\circ} \mathrm{C}$ for $1 \mathrm{hr}$ (21.00 days) respectively. Further, maximum size of calli $(11.90 \mathrm{~mm})$ was reported in treatment where ovaries were exposed to $35^{\circ} \mathrm{C}$ for $2 \mathrm{hr}$ and was found to be statistically superior from all other treatment combinations, while maximum shoot differentiation rate $(20.85 \%)$ that showed significant superiority from all other treatment combinations was reported when ovaries were pretreated at $45{ }^{\circ} \mathrm{C}$ for $2 \mathrm{hr}$. In summary pretreatment of flower buds at $45^{\circ} \mathrm{C}$ for $2 \mathrm{hr}$ was found to be beneficial for callus induction as well as for shoot differentiation from in vitro ovary culture of marigold (Table $3)$.

\section{Effect of varying concentrations of sucrose on callus induction and shoot differentiation rate}

Asheat pretreatment of flower buds at $45{ }^{\circ} \mathrm{C}$ for $2 \mathrm{hrs}$ was standardized best for callus induction and shoot differentiation, thus, here $20 \mathrm{~mm}$ long young flower buds were exposed to $45{ }^{\circ} \mathrm{C}$ for $2 \mathrm{hr}$ and ovaries from these buds after surface sterilization were cultured on MS media supplemented with $4.44 \mu \mathrm{M}$ BAP and $4.52 \mu \mathrm{M} 2$, 4-D with different concentration of sucrose $(0,2,4,6,8,10,12 \%)$ in order to find out the effect of varying concentrations of sucrose on callus induction and shoot differentiation. However, it was found that callus induction rate on medium with $0 \%, 2 \%$, $4 \%, 6 \%, 8 \%, 10 \%$ and $12 \%$ sucrose were significant (Tab2). But, highest callus induction rate $(89.66 \%)$ was reported in media having $4 \%$ and $6 \%$ sucrose followed by in media having $2 \%$ sucrose $(87.48$ $\%)$.Also, the treatment ( $4 \%$ and $6 \%$ sucrose) was found to be statistically at par with $2 \%$ sucrose treatment. Consequently, as the concentration of sucrose in media increases from $8 \%$ to $12 \%$, size of the calli reduces drastically. 
Table.1 Effect of heat pretreatment on callus induction and shoot differentiation from ovary culture of marigold

\begin{tabular}{|c|c|c|c|c|}
\hline $\begin{array}{c}\text { Temperature } \\
\left({ }^{0} \mathbf{C}\right)\end{array}$ & $\begin{array}{c}\text { Callus Induction } \\
\text { rate }(\boldsymbol{\%})^{\mathbf{a}}\end{array}$ & $\begin{array}{c}\text { Days to callus } \\
\text { induction }\end{array}$ & $\begin{array}{c}\text { Calli size } \\
(\mathbf{m m})\end{array}$ & $\begin{array}{c}\text { Shoot differentiation } \\
\text { rate }(\%)^{\mathbf{b}}\end{array}$ \\
\hline $\mathbf{2 5}$ & 87.88 & 21.00 & 7.27 & 1.43 \\
\hline $\mathbf{3 5}$ & 83.72 & 21.85 & 7.70 & 8.71 \\
\hline $\mathbf{4 5}$ & 85.57 & 23.05 & 5.20 & 10.78 \\
\hline SEM & 0.02 & 0.09 & 0.04 & 0.08 \\
\hline CD at 5\% & 0.06 & 0.26 & 0.12 & 0.25 \\
\hline
\end{tabular}

Table.2 Effect of heat pretreatment duration on callus induction and shoot differentiation from ovary culture of marigold

\begin{tabular}{|c|c|c|c|c|}
\hline $\begin{array}{c}\text { Duration } \\
(\mathbf{h r})\end{array}$ & $\begin{array}{c}\text { Callus Induction } \\
\text { Rate }(\boldsymbol{\%})^{\mathbf{a}}\end{array}$ & $\begin{array}{c}\text { Days to Callus } \\
\text { Induction }\end{array}$ & $\begin{array}{c}\text { Calli size } \\
(\mathbf{m m})\end{array}$ & $\begin{array}{c}\text { Shoot Diffe- } \\
\text { rentiation Rate (\%) }\end{array}$ \\
\hline $\mathbf{1}$ & 90.48 & 21.00 & 7.87 & 1.43 \\
\hline $\mathbf{3}$ & 92.12 & 21.20 & 8.80 & 12.38 \\
\hline $\mathbf{5}$ & 89.14 & 22.00 & 7.07 & 12.66 \\
\hline $\mathbf{8}$ & 71.16 & 23.67 & 3.16 & 1.43 \\
\hline SEm & 0.025 & 0.10 & 0.05 & 0.10 \\
\hline CD at 5 \% & 0.07 & 0.30 & 0.14 & 0.28 \\
\hline
\end{tabular}

${ }^{\mathrm{a}}$ Callus Induction Rate $(\%)=($ No. of callus formed $/$ No. of ovarys inoculated $) \times 100$.

${ }^{\mathrm{b}}$ Shoot Differentiation Rate $(\%)=$ (No. of callus generating shoots in differentiation medium / No. of callus inoculated) $\times 10$

Table.3 Effect of heat pretreatment temperature and duration on callus induction and shoot differentiation from ovary culture of marigold

\begin{tabular}{|c|c|c|c|c|c|}
\hline \multicolumn{2}{|c|}{$\begin{array}{l}\text { Temperature }\left({ }^{\circ} \mathbf{C}\right) \times \\
\text { duration }(\mathbf{h r})\end{array}$} & \multirow{2}{*}{$\begin{array}{l}\text { Callus Induction } \\
\text { Rate }(\%)^{\text {a }} \\
89.66\end{array}$} & \multirow{2}{*}{$\begin{array}{c}\text { Days to Callus } \\
\text { Induction } \\
21.00\end{array}$} & \multirow{2}{*}{$\begin{array}{c}\text { Calli size }(\mathrm{mm}) \\
7.90\end{array}$} & \multirow{2}{*}{$\begin{array}{l}\text { Shoot Differentiation Rate } \\
\qquad(\%)^{\text {b }} \\
1.43\end{array}$} \\
\hline $25^{\circ} \mathrm{C}$ & $1 \mathrm{hr}$ & & & & \\
\hline & $3 \mathrm{hr}$ & 89.66 & 21.00 & 7.50 & 1.43 \\
\hline & $5 \mathrm{hr}$ & 89.66 & 21.00 & 7.20 & 1.43 \\
\hline & $8 \mathrm{hr}$ & 82.63 & 21.00 & 6.50 & 1.43 \\
\hline \multirow[t]{4}{*}{$35^{\circ} \mathrm{C}$} & $1 \mathrm{hr}$ & 89.66 & 21.00 & 7.90 & 1.43 \\
\hline & $3 \mathrm{hr}$ & 89.66 & 20.60 & 11.90 & 14.85 \\
\hline & $5 \mathrm{hr}$ & 89.66 & 21.40 & 9.00 & 17.14 \\
\hline & $8 \mathrm{hr}$ & 65.91 & 24.40 & 2.00 & 1.43 \\
\hline \multirow[t]{4}{*}{$45^{\circ} \mathrm{C}$} & $1 \mathrm{hr}$ & 92.13 & 21.00 & 7.80 & 1.43 \\
\hline & $3 \mathrm{hr}$ & 97.05 & 22.00 & 7.00 & 20.85 \\
\hline & $5 \mathrm{hr}$ & 88.10 & 23.60 & 5.00 & 19.43 \\
\hline & $8 \mathrm{hr}$ & 65.00 & 25.60 & 1.00 & 1.43 \\
\hline SEm & & 0.04 & 0.18 & 0.08 & 0.17 \\
\hline CD at $5 \%$ & & 0.12 & 0.52 & 0.24 & 0.49 \\
\hline
\end{tabular}

${ }^{\mathrm{a}}$ Callus Induction Rate $(\%)=($ No. of callus formed $/$ No. of ovarys inoculated $) \times 100$.

${ }^{\mathrm{b}}$ Shoot Differentiation Rate $(\%)=$ (No. of callus generating shoots in differentiation medium / No. of callus inoculated) $\times 100$. 
Table.4 The effect of different concentration of sucrose on callus induction, days to callus induction, size of calli from ovary culture of marigold cultivar 'Arka Agni'

\begin{tabular}{|c|c|c|c|l|c|}
$\begin{array}{c}\text { Sucrose } \\
\text { concentration }\end{array}$ & $\begin{array}{c}\text { Callus } \\
\text { Induction } \\
\text { Rate }(\%)^{1}\end{array}$ & $\begin{array}{c}\text { Days to } \\
\text { Callus } \\
\text { Induction }\end{array}$ & $\begin{array}{c}\text { Callus } \\
\text { size }\end{array}$ & $\begin{array}{c}\text { Callus growth } \\
\text { pattern }\end{array}$ & $\begin{array}{c}\text { Shoot } \\
\text { Differentiation } \\
\text { Rate }(\%)^{2}\end{array}$ \\
\hline $\mathbf{0 \%}$ & $2.34^{\mathrm{e}}$ & $30.00^{\mathrm{e}}$ & $1.00^{\mathrm{f}}$ & ovary dried & $0.34^{\mathrm{d}}$ \\
\hline $\mathbf{2 \%}$ & $96.48^{\mathrm{a}}$ & $23.67^{\mathrm{d}}$ & $3.10^{\mathrm{b}}$ & yellowish green calli & $19.31^{\mathrm{b}}$ \\
\hline $\mathbf{4 \%}$ & $98.66^{\mathrm{a}}$ & $24.00^{\mathrm{d}}$ & $4.43^{\mathrm{a}}$ & White compactcalli & $22.59^{\mathrm{a}}$ \\
\hline $\mathbf{6 \%}$ & $97.66^{\mathrm{a}}$ & $25.00^{\mathrm{c}}$ & $3.00^{\mathrm{b}}$ & white calli & $9.72^{\mathrm{c}}$ \\
\hline $\mathbf{8 \%}$ & $75.05^{\mathrm{b}}$ & $26.00^{\mathrm{b}}$ & $1.93^{\mathrm{c}}$ & White calli & $0.34^{\mathrm{d}}$ \\
\hline $\mathbf{1 0 \%}$ & $70.68^{\mathrm{c}}$ & $26.33^{\mathrm{b}}$ & $1.40^{\mathrm{d}}$ & White calli & $0.34^{\mathrm{d}}$ \\
\hline $\mathbf{1 2 \%}$ & $62.09^{\mathrm{d}}$ & $30.00^{\mathrm{a}}$ & $1.00^{\mathrm{e}}$ & White calli & $0.34^{\mathrm{d}}$ \\
\hline
\end{tabular}

${ }^{1}$ Callus Induction Rate $(\%)=($ No. of callus formed $/$ No. of anthers inoculated $) \times 100.100$ anthers were inoculated in one petri dish

${ }^{2}$ Shoot differentiation Rate $(\%)=$ (No. of callus generating shoots in differentiation medium / No. of callus inoculated) $\times 100$

Table.5 The effect of different dark duration on callus induction rate (\%), days to callus induction, size of calli and shoot differentiation rate from ovary culture of marigold

\begin{tabular}{|c|c|c|c|}
\hline $\begin{array}{c}\text { Dark period } \\
\text { (week) }\end{array}$ & $\begin{array}{c}\text { Callus Induction } \\
\text { Rate }(\%)^{1}\end{array}$ & Callus size & $\begin{array}{c}\text { Shoot Differentiation } \\
\text { Rate }(\%)^{2}\end{array}$ \\
\hline 0 & $20.34^{\mathrm{d}}$ & $1.50^{\mathrm{f}}$ & $0.34^{\mathrm{c}}$ \\
\hline 1 & $20.34^{\mathrm{d}}$ & $1.50^{\mathrm{f}}$ & $0.34^{\mathrm{c}}$ \\
\hline 2 & $40.34^{\mathrm{c}}$ & $2.50^{\mathrm{e}}$ & $14.38^{\mathrm{b}}$ \\
\hline 3 & $75.19^{\mathrm{b}}$ & $3.60^{\mathrm{d}}$ & $23.72^{\mathrm{a}}$ \\
\hline 4 & $99.66^{\mathrm{a}}$ & $4.53^{\mathrm{c}}$ & $23.35^{\mathrm{a}}$ \\
\hline 5 & $99.66^{\mathrm{a}}$ & $4.90^{\mathrm{b}}$ & $0.34^{\mathrm{c}}$ \\
\hline 6 & $99.66^{\mathrm{a}}$ & $5.07^{\mathrm{a}}$ & $0.34^{\mathrm{c}}$ \\
\hline
\end{tabular}

${ }^{1}$ Callus Induction Rate $(\%)=($ No. of callus formed $/$ No. of ovary inoculated $) \times 100.70$ ovary were inoculated in one petri dish

${ }^{2}$ Shoot differentiation Rate $(\%)=$ (No. of callus generating shoots in differentiation medium / No. of callus inoculated) $\times 100$

Fig.1 Marigold cv. 'Arka Agni'

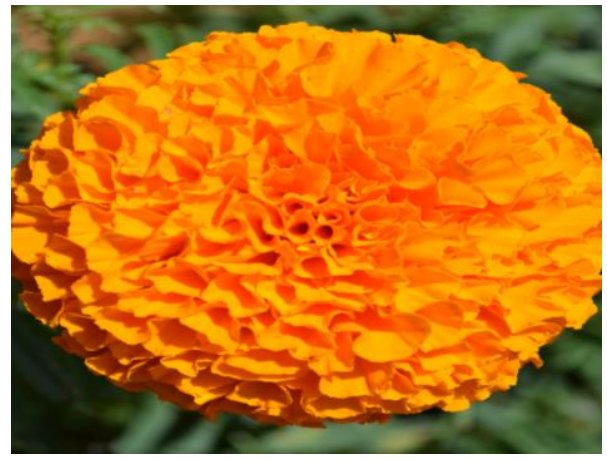


Fig.2 Unfertilized ovary culture of maigold cv. 'Arka Agni’
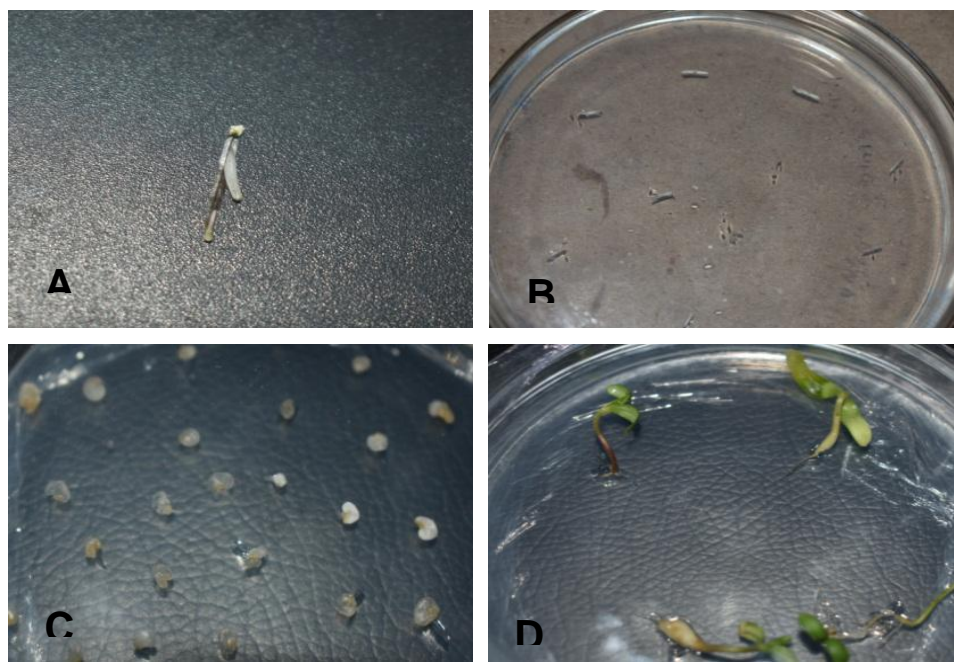

A) Ovule inside ovary B) No growth hormone C) $4.44 \mu \mathrm{M}$ BAP + $2.68 \mu \mathrm{M}$ NAA D) $4.44 \mu \mathrm{M}$ BAP $+4.52 \mu \mathrm{M} 2,4$ $\mathrm{D}$

Fig.3 A) Callus initiation B) Shoot differentiation from unfertilized ovary culture of marigold cv 'Arka Agni'
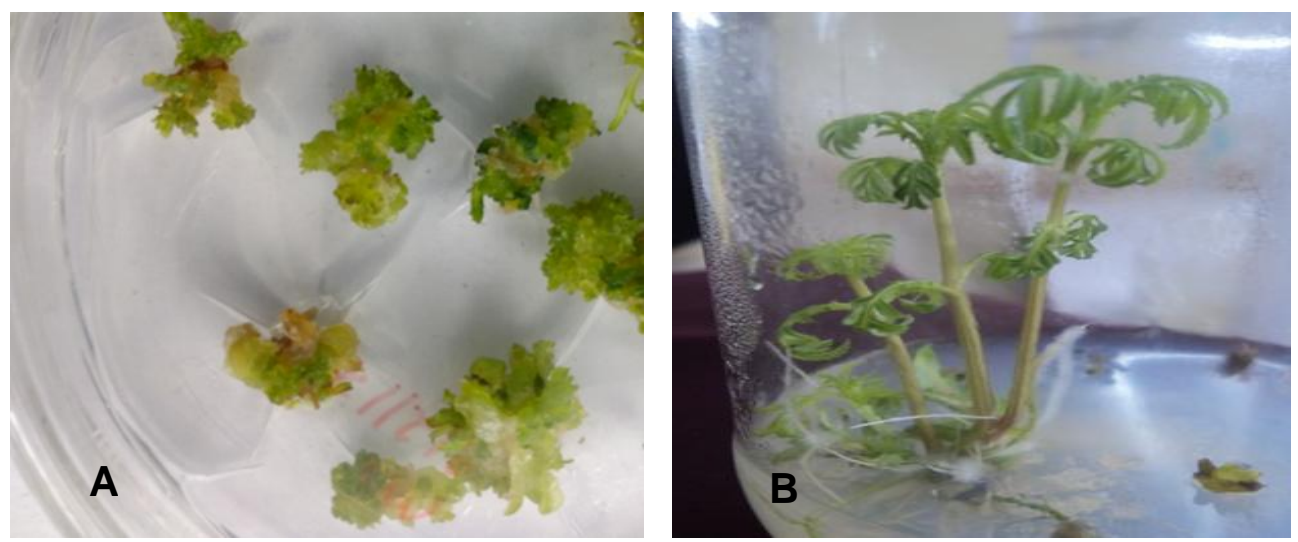

Fig.4 Rooting of plantlet developed from unfertilized ovary culture of marigold cv. 'Arka Agni'
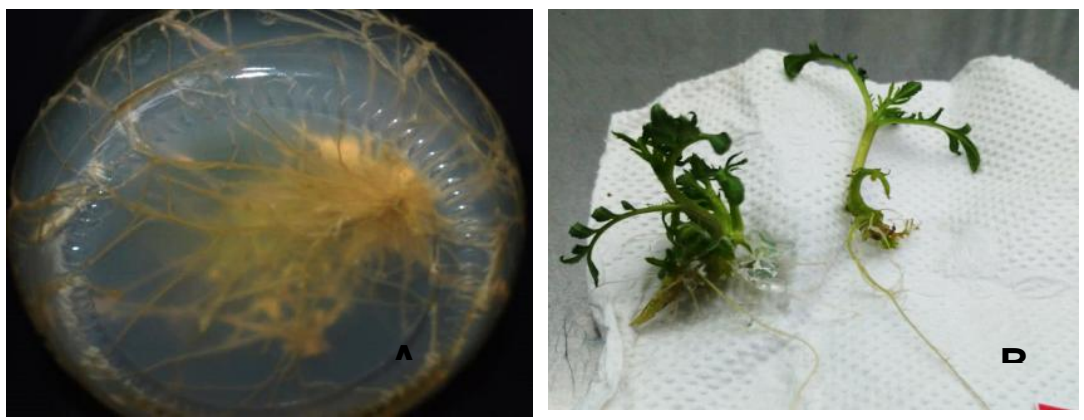

A) Rooting on MS media without plant growth regulators

B) Rooting on MS media supplemented with $1.47 \mu \mathrm{M}$ IBA 
Furthermore, maximum calli size $(4.43 \mathrm{~mm})$ was found in media with $4 \%$ sucrose, whereas found no callus induction in media with $0 \%$ sucrose.

\section{Effect of dark treatment on callus induction and shoot differentiation rate}

Thus, after standardizing the best pretreatment to flower bud (temperature and duration) and concentration of sucrose in culture media, the next step was to find out the best dark incubation period for callus development and shoot differentiation rate from cultured ovaries. It was found that callus number and diameter increased as the dark period duration increased (Table 3), further callus continued to grow over the entire 6week dark treatment. Accordingly, highest callus induction rate $(89.66 \%)$ was reported in 4 to 6 week of dark treatment which was found to be statistically superior from other treatments. On the contrary, ovaries exposed to continuous light without dark period became green in colour with no callus initiation. Hence, callus induction was promoted under darkness but was inhibited by continuous exposure to light. As a consequence, callus with largest diameter $(5.07 \mathrm{~mm})$ was reported in plates that were exposed to longest dark period of 6 weeks and was found statistically superior from all other treatments. Though the number and size of callus was found to increase continuously for 6 weeks of dark incubation, nevertheless, callus quality and appearance decreased noticeably during this period. Furthermore, the maximum shoot differentiation rate was reported in 3-week dark treatment $(23.72 \%)$ which was found to be statistically at par with 4 week dark treatment (23.35 \%) (Fig. 2). Hence, 4-week dark incubation of ovary culture followed by $16 \mathrm{hr}$ photoperiod was standardized as the best for callus induction and shoot differentiation for in vitro ovary culture.
Apart from genotype and plant growth regulators, the other main parameters that have a critical influence on the success of gynogenesis are the stress treatments applied to in vitro cultural conditions. These are large set of conditions that include temperature as pretreatment to flower buds or ovaries, excess and deficiency of carbohydrates in culture media and exposure of ovary after culture to different durations of dark-light period. These stress treatments may have a considerable influence on embryo induction and are also important factors that switch the gamete development from the gametophytic pathway to saprophytic pathway (Wędzony et al., 2009). In this experiment, maximum callus induction $(89.66 \%)$ was reported when ovaries were pretreated at $25{ }^{\circ} \mathrm{C}, 35^{\circ} \mathrm{C}$ for 1 , 2 or $5 \mathrm{hr}$ and at $45^{\circ} \mathrm{C}$ for 1 or $2 \mathrm{hr}$. Similarly, Tantasawat et al., (2015) found that the percentages of callus formation were similar under both 25 and $35{ }^{\circ} \mathrm{C}(54.00$ and $52.31 \%$ respectively) in cucumber ovary culture. Koli and Murthy, 2013) incubated the melon and cucumber ovule at $25{ }^{\circ} \mathrm{C}$ with $16 \mathrm{~h}$ light and 8 $\mathrm{h}$ dark for 8 weeks and obtained callus or embryos, respectively. In addition, the present experiment proves that $45{ }^{\circ} \mathrm{C}$ for $8 \mathrm{hr}$ pretreatment drastically reduces the callus induction rate $(46.67 \%)$ and results in smallest size callus $(1 \mathrm{~mm})$. Likewise, Tantasawat et al., (2015) also reported that thermal shock at $35{ }^{\circ} \mathrm{C}$ for 3 days significantly reduces the percentages of cucumber embryo-like structure formation. Besides, it was also observed that the minimum days were taken to callus initiation (20.60 days), in ovaries pretreated at $35{ }^{\circ} \mathrm{C}$ for $2 \mathrm{hr}$, whereas, maximum size of calli $(11.90 \mathrm{~mm})$ was reported in treatment where ovaries were exposed to $35{ }^{\circ} \mathrm{C}$ for $2 \mathrm{hr}$ and was found to be statistically superior from all other treatment combinations. Consequently, maximum shoot differentiation rate $(20.85 \%)$ was observed in ovaries pretreated at $45{ }^{\circ} \mathrm{C}$ for $2 \mathrm{hr}$ which was found to be significantly 
superior to all other treatment combinations. Similar results have been reported in other crops, for example, in case of summer squash, ovules exposed to $32{ }^{\circ} \mathrm{C}$ for 4 days produced the greatest number of gynogenic ovules (28 \%) (Shalaby, 2007). As well, Sun et al., (2009) proved that heat treatment at $35^{\circ} \mathrm{C}$ for 6 days before embryo induction remarkably enhances the potential of embryo formation through in vitro unpollinated pumpkin ovary culture. Correspondingly, Ge'mes-Juha'sz et al., (2002) demonstrated that heat treatment at $32{ }^{\circ} \mathrm{C}$ during the embryonic induction phase increases haploid embryo formation and plantlet regeneration from ovule cultures of cucumber, where the maximum frequency of gynogenesis and maximum plant regeneration were 18.4 and $7.1 \%$, respectively. Besides, a thermal shock at $35{ }^{\circ} \mathrm{C}$ for 3 days results in higher frequency of cucumber embryo formation than the same treatment for 3 or 4 days [Diao et al., (2009), Moqbeli et al., (2013)]. Likewise, Golabadi et al., 2017 also reported that the most embryogenesis $(38.98 \%)$ in ovary culture of cucumber occurred during the thermal shock pretreatment. However, Min et al., 2016 proved that heat shock $\left(35{ }^{\circ} \mathrm{C}\right)$ for 5 days could help pumpkin ovaries turn green and induce embryoids.

Accordingly, sucrose concentration in induction medium that is usually used at concentration of $30 \mathrm{~g} \mathrm{~L}^{-1}$ has a major effect on osmosis, which in turn has significant effect on embryonic development. Shalaby (2007) has reported that in summer squash, as the concentration of sucrose increases $(30,60$ and $90 \mathrm{~g} \mathrm{~L}^{-1}$ ), the percentage of ovules forming embryos decreases. However, ovules cultured on MS medium containing $30 \mathrm{~g} \mathrm{~L}^{-1}$ yield the best results, whereas ovules cultured on medium supplemented with $90 \mathrm{~g} \mathrm{~L}^{-1}$ do not produce embryos at all. For haploid induction, nevertheless, its optimum concentration may vary according to the species (Hidaka, 1984).
However, it was found that $6 \%$ sucrose promoted embryo formation, but inhibited proliferation of somatic tissues in unfertilized ovary culture of wheat (Mukhambetzhanov 1992). Also, high sucrose concentration in the culture medium has been shown to be beneficial in some plant species such as carnation (Sato et al., 2000) and shallot (Sulistyaningsih et al., 2006). In our experiment we found that, highest callus induction rate $(89.66 \%)$ was reported in media having $4 \%$ and $6 \%$ sucrose followed by in media having $2 \%$ sucrose $(87.48 \%)$. Correspondingly, in the present experiment, as the concentration of sucrose in media was increased from $8 \%$ to $12 \%$, size of the calli reduced drastically. Whereas, maximum calli size $(4.43 \mathrm{~mm})$ was found in media with $4 \%$ sucrose, but observed no callus induction in media with $0 \%$ sucrose. Likewise, Zhang, 2012 reported that MS supplemented with 6BA $2.0 \mathrm{mg} \mathrm{L}^{-1}+$ NAA0.5mg L ${ }^{-1}+$ sucrose $60 \mathrm{~g}$ $\mathrm{L}^{-1}$ was good for callus induction from ovary culture of ground cover chrysanthemum. Also, Toprakand Alan, 2016 observed that leek flower buds cultured in sucrose-free media failed to develop and no gynogenic plantlets were developed. Further, they also suggest that addition of $100 \mathrm{~g} \mathrm{~L}^{-1}$ sucrose into the induction medium (BDS) is necessary for a successful gynogenesis induction in leek.

Though ovaries/ovules are generally cultured in light, but in some species, e.g., saffron (Bhagyalakshmi, 1999) and cucumber (Ge'mes-Juha'sz et al., 2002) dark incubation favors gynogenesis and minimize somatic callusing. On the contrary, high illumination has been reported to be beneficial for onion (Puddephat et al., 1999) in this experiment, it was found that callus number and diameter increased as the dark period duration increased (Table 3) and callus continued to grow over the entire 6-week dark treatment. Thus, highest callus induction rate $(89.66 \%)$ was reported in 4 to 6 weeks of dark 
treatment, whereas ovaries exposed to continuous light without dark period turned green with no callus initiation. However, largest callus diameter $(5.07 \mathrm{~mm})$ was reported in ovary cultured plates that was exposed to longest dark period of 6 weeks and found to be statistically superior from all other treatments. Although the number and size of callus may continue to increase for 6 weeks of dark incubation, callus quality and appearance decreased noticeably during this period. Further, the maximum shoot differentiation rate was reported in 3-weeks dark treatment $(23.72 \%)$ which was found to be statistically at par with 4 week dark treatment $(23.35 \%)$. On the other hand, Zhang, 2012 reported that, Ovule callus induction rate under light condition was significantly higher than under the dark conditions from ovule culture of chrysanthemum (Table 4 and 5).

In summary, effects of various stress treatments was assessed and a protocol where young and healthy $20 \mathrm{~mm}$ long flower buds pretreated at $45{ }^{\circ} \mathrm{C}$ for $2 \mathrm{hr}$ placed in MS media supplemented with $4 \%$ sucrose +4.44 $\mu \mathrm{M}$ BAP $+4.52 \mu \mathrm{M} 2,4-\mathrm{D}$ for callus induction followed by dark incubation of plates for 4 weeks and finally, transfer of ovary derived calli to MS media supplemented with $4 \%$ sucrose $4.44 \mu \mathrm{M}$ BAP $+1.07 \mu \mathrm{M}$ NAA for shoot differentiation was developed and standardized for ovary culture of marigold cultivar Arka Agni.

\section{References}

Bhagyalakshmi, N. 1999. Factors influencing direct shoot regeneration from ovary explants of saffron. Plant Cell Tissue Organ Cult. 58: 205-211.

Bohanec, B. 2009. Doubled Haploids via Gynogenesis. In: Advances in Haploid Production in Higher Plants (Eds.) Touraev, A., Forster, BP and Jain, SM.
Springer Science, Business Media B.V, ISBN 978-1-4020-8853-7.pp. 35-46.

Chen, J.F., Cui, L., Malik, AA andMbira, KG. 2011. In vitro haploid and dihaploid production via unfertilized ovule culture. Plant Cell Tiss Organ Cult.104: 311-319.

Diao, W.P., Jia, Y.Y., Song, H., Zhang, XQ., Lou, QF and Chen, JF. 2009. Efficient embryo induction in cucumber ovary culture and homozygous identification of the regenerants using SSR markers. Sci. Hortic. 119: 246-251.

Ge'mes-Juha'sz, A., Balogh, P., Ferenczy, A and Kristo'f, Z. 2002. Effect of optimal stage of female gametophyte and heat treatment on in vitro gynogenesis induction in cucumber (Cucumis sativus L.). Plant Cell Rep.21:105-111.

Golabadi, M., Ghanbari, S., Keighobadi, K and Ercisli, S. 2017. Embryo and callus induction by different factors in ovary culture of cucumber. J. App Bot. Food Qual.90:68-75. DOI:10.5073/JABFQ.2017.090.010.

Hidaka, T. 1984. Effect of sucrose concentration, $\mathrm{Ph}$ of media, and culture temperature on anther culture of citrus. Japan. J. Breed.34: 416-422.

Koli, SP and Murthy, HN. 2013. Haploid plant regeneration from unpollinated ovules of Cucumis melo L. var. Conomon cv. Mudicode. British Biotech. J.3: 605-613.

Li, F., Tang, D and Liang, S. 2007. Effects of growth regulators on anther culture of marigold. J. Qinghai Uni. (Nature Science).1:12.

Min, Z.Y., Li, H., Zou, T., Tong, L., Cheng, J and Sun, XW. 2016. Studies of in vitro culture and plant regeneration of unfertilized ovary of pumpkin. Chin Bull Bot. 51(1): 74-80.

Moqbeli, E.G., Peyvast, Y., Hamidoghli and Olfati, JA. 2013. In vitro cucumber haploid line generation in several new 
cultivars. Asia Pacific J. Mol. Biol.21: $18-25$.

Mukhambetzhanov, SK. 1992. Growth and morphogenesis of nonfertilized ovaries of wheat in vitro. Ph.D thesis, Main botanical garden acad of sci of Kazakstan, Alma-Ata.

Murashige, T and Skoog, F. 1962. A revised medium for rapid growth and bioassays with tobacco tissue culture. Physiologiae Plantarum. 15:472-497.

Musial, K., Bohanec, B., Jakše, M andPrzywara, L. 2005. The development of onion (Allium cepa L.) embryo sacs in vitro and gynogenesis induction in relation to flower size. In Vitro Cellular and Developmental Biology-Plant.41:446-452.

Puddephat, I.J., Robinson, HT and Smith, BM. 1999. Influence of stock plant pretreatment on gynogenic embryo induction from buds of onion. Plant Cell Tissue Organ Cult.57:145-148.

Sato, S., Katoh, N., Yoshida, H., Iwai, S and Hagimori, M. 2000.Production of doubled haploid plants of carnation (Dianthus caryophyllus L.) by pseudofertilized ovule culture. Sci Hort.83: 301- 310.

Shalaby, TA. 2007. Factor affecting haploid induction through in vitro gynogenesis in summer squash (Cucurbita pepo L.). ScientiaHortic.115: 1-6.

Sulistyaningsih, E., Aoyagi, Y and Tashiro, Y. 2006. Flower bud culture of shallot (Allium cepa L. aggregatum group) with cytogenetic analysis of resulting gynogenic plants and somaclones. Plant Cell Tissue Organ Cult. 86:249-255.

Sun, S., Zhai, Q., Hu, J., Chen, J andZhang, P. 2009. Effects of several physiological factors on embryo formation in unpollinated ovary culture of pumpkin. Plant. Physi. Communications. 45(10): 977-980.

Tantasawat, PA., Sorntip, A., Poolsawat, O., Chaowiset, $\mathrm{W}$ and Pornbungkerd, P.2015. Evaluation of Factors Affecting Embryo-like Structure and Callus Formation in Unpollinated Ovary Culture of Cucumber (Cucumis sativus).IJAB.17: 613-618.

Toprak, FC and Alan, AR. 2016. Optimization of gynogenesis induction in leek (Allium ampeloprasum var. porrum).J. Biotechnol.231S: S4-S109.

Wędzony, M., Forster, BP., Żur, I., Golemiec, E., Szechyńska-Hebda, M., Dubas, E and Gotębiowska, G. 2009.Progress in doubled haploid technology in higher plants. In: Advances in haploid production in higher plants, Springer Netherlands.pp. 1-33.

Yingchun, Q., Yaomei, Y and Manzhu, B. 2011.Establishment of plant regeneration system from anther culture of Tagetes patula. Afr. J Biotechnol. 10:17332-17338.

Zhang, Z. 2012. Unpollinated Ovule Culture of Ground-cover Chrysanthemum (Chrysanthemum $\times$ grandiflorum). MSc thesis, Beijing Forestry University. Available from http://www.dissertation topic.net/doc/1793775.

\section{How to cite this article:}

Thaneshwari, C. Aswath and Chaithra, N. 2018. Stress Induced Callus Initiation and Shoot Regeneration in Ovary Culture of Marigold (Tagetes spp). Int.J.Curr.Microbiol.App.Sci. 7(03): 3216-3226. doi: https://doi.org/10.20546/ijcmas.2018.703.372 